\title{
Assessment of Association Between Arch Shape and Dental Malocclusion Among Out Patients in A Private Dental Setup- A Retrospective Study
}

\author{
Noorul Aneesa, Nivethigaa Balakrishnan* and Mahesh Ramakrishnan \\ Saveetha Dental College and Hospitals, Saveetha Institute of Medical and \\ Technical Science, Saveetha University, Chennai India \\ Corresponding author email: nivethigaab.sdc@saveetha.com
}

\section{ABSTRACT}

Arch shape reflects the underlying shape of the basal bone, which is predetermined for every individual. It cannot be altered unless a surgical procedure is performed to permanently change the size and shape of jaws. Deviation from the ideal features of occlusion results in malocclusion in the dental arches. The purpose of the present study was to evaluate the relationship between the arch shape and dental malocclusion classified based on angles classification of malocclusion. Samples in the age group of 18-50 years were collected from among the out-patient records. Similar number of samples (100) were chosen in each of the subgroups based on the angle classification. Arch shape in each of the samples were analysed and tabulated. Patient intraoral pictures were used for this purpose. Pearson's Chi square test was done to find the association between the type of dental malocclusion and arch shape. Results of the study revealed that class I and class II Division malocclusion was predominantly associated with U shaped arches, whereas Class II division 1 malocclusion was associated with V shaped arches and Class III malocclusion with square shaped dental arches. The results showed that there is an association between the type of malocclusion and shape of the dental arches and hence planning for correction of any malocclusion should be made unique specifying the shape of the dental arches.

\section{KEY WORDS: ANOMALIES, ARCH SHAPES, MALOCCLUSION, MAL RELATIONSHIP,}

\section{INTRODUCTION}

Deviation from the ideal features of occlusion results in malocclusion in the dental arches. Dental malocclusion was originally classified by many authors, of which the Angles classification is the most accepted. Based on the angle's classification, inter-arch relationship can be broadly classified as Class I, Class II Division 1 and 2 and class III. Numerous experts for more than a hundred years now have offered descriptions of the shapes and the sizes of maxillary dental arches. The first classification for dental arch forms proposed three main forms - narrowed, square and oval. At the same time, research data and clinical observations suggest that maxillary dental arch forms in humans can

Biosc Biotech Res Comm P-ISSN: 0974-6455 E-ISSN: 2321-4007

\section{crossef}

Identifiers and Pagination

Year: 2021 Vol: 14 No (10) Special Issue

Pages: 134-137

This is an open access article under Creative

Commons License Attribn 4.0 Intl (CC-BY). DOI: $h t t p: / / d x$.doi.org/10.21786/bbrc/14.10.22 be described with considerable diversity (Dunn, 1937; Weinstein and Zientz, 2016; Ke et al., 2019; Sathish and Karthick, 2020).

The dental arch, an important element in orthodontics, is a fundamental principle in orthodontic planning and therapy. A dental arch form is initially established by the configuration of the bony ridge and then by tooth eruption, perioral muscles, and intraoral functional forces. Even though most patients with a malocclusion have an altered dental arch form, the alterations achieved with mechanics during orthodontic treatment should not affect the balance between bone and dental and muscular structures; the arrangement of these structures adjacent to teeth and jaws should be considered the limit for orthodontic movement (Strang, 1946). It cannot be altered unless a surgical procedure is performed to permanently change the size and shape of jaws. Altering arch shape during the shape of the arches, results in loss of stability of the treatment results achieved during orthodontic treatment (Jain et al., 2019; Jose et al., 2020).
Article Information

Received: $10^{\text {th }}$ Aug 2021 Accepted after revision: $25^{\text {th }}$ Oct 2021 
Previously our team has a rich experience in working on various research projects across multiple disciplines (Gheena and Ezhilarasan, 2019; Ke et al., 2019; Malli et al., 2019; Mehta et al., 2019; Samuel et al., 2019; Sharma et al., 2019; Varghese et al., 2019; Venu et al., 2019; Vignesh et al., 2019; Jain et al., 2019; Jose et al., 2020; Krishnaswamy et al., 2020; Muthukrishnan et al., 2020; Samuel et al., 2020; Sathish and Karthick, 2020). Now the growing trend in this area motivated us to pursue this project. The purpose of the present study was to evaluate the relationship between the arch shape and dental malocclusion classified based on angles classification of malocclusion.

\section{MATERIAL AND METHODS}

This was a retrospective study planned in a university set up among the patients under the age group of 18 to 50 years who visited Saveetha Dental College for dental check-up. Ethical approval was obtained from the Institutional ethical committee (SDC/SIHEC/2020/ DIAS DATA/ 0619-0320). A total of 400 patients were selected with a simple random sampling technique with 100 cases in each sub group segregated based on the dental malocclusion classified with Angles classification of malocclusion. Parameters tabulated include type of dental malocclusion and shape of the dental arch. The Inclusion criteria included high quality and clear pictures of patients that were between the age group of 18 to 50 years consisting of full set permanent dentition, exclusion criteria which includes incomplete dental records, and among those who previously underwent orthodontic treatment. The data was tabulated in excel sheets. Statistical analysis was done with IBM SPSS (version 26.0). Descriptive statistics was done to analyse distribution of various arch shapes in each malocclusion. Inferential statistics using Pearson's chi-square test was done to find the association between the different arch shapes and dental malocclusion.

\section{RESULTS AND DISCUSSION}

A total of 400 patients were selected and sorted based on age (18-50 years) and were divided into 4 groups based on their malocclusions. 100 patients from the overall population were selected randomly from each group. Patients having incomplete case sheets records were excluded from the study. With an overall population count of 400 patients Majority of patients (215 patients) had U-shaped arch, 82 patients had V-shaped arch, 65 of them square shaped arch and 38 of them had oval shaped arch. Out of 100 patients with class 1 malocclusion, $72 \%$ of the patients had U-shaped arch, 13\% of the patients had V-shaped arch, $10 \%$ of the patients had oval shaped arch and whereas $5 \%$ of the patients had square shaped arch. Out of 100 patients with class 2 div 1 malocclusion $38 \%$ of the patients had U-shaped arch, $50 \%$ of the patients had V-shaped arch, $5 \%$ of the patients had square shaped arch and whereas $7 \%$ of the patients had oval shaped arch.

Out of 100 patients with class 2 div 2 malocclusion $76.2 \%$ of the patients had U-shaped arch, $5.9 \%$ of the patients had V-shaped arch, $5.9 \%$ of the patients had square shaped arch and whereas $7.9 \%$ of the patients had oval shaped arch.
Out of 100 patients with class 3 malocclusion, $28.2 \%$ of the patients had U-shaped arch, $14 \%$ of the patients had V Shape arch, $13.8 \%$ of the patients had oval shaped arch $46 \%$ of the patients had square shaped arch. On association between various arch shapes and malocclusion it is inferred that $\mathrm{u}$-shape arch is more prevalent in class 1 and class 2 div 2 malocclusions, whereas v-shaped arch is more prevalent in class $2 \operatorname{div} 1$ and class 3 malocclusion has a maximum number of square shaped arch, with a p value of $0.03(<0.05$, hence statistically significant) (Figure 1).

Figure 1: The bar graph depicts association between dental malocclusion (classified based on angles classification) and presence of different arch shapes. $\mathrm{X}$-axis shows different malocclusion and $y$-axis shows the number of patients with various malocclusion. (Chi square test $p$ value- $0.03(<0.05$, hence statistically significant). From the above graph it is inferred that $U$ shape arch is more prevalent in class 1 and class 2 div 2 malocclusions, whereas $V$ shape arch is more prevalent in class 2 div 1 and class 3 malocclusion has a maximum number of square shaped arch, and difference was found to be statistically significant.

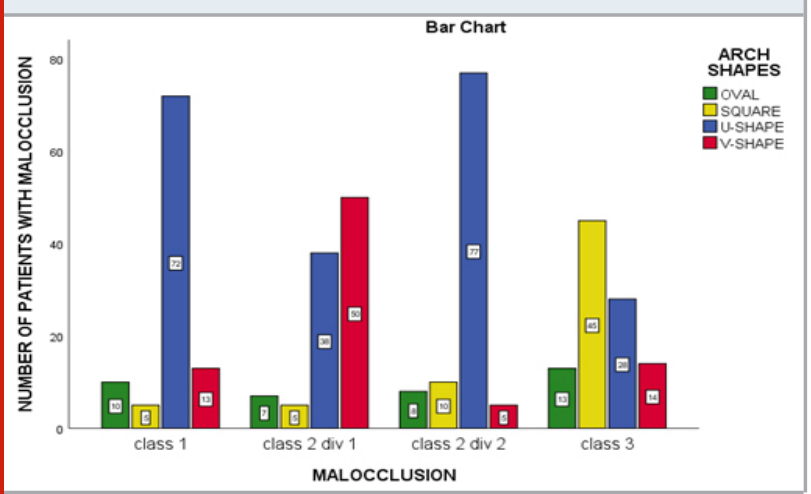

Significant differences were identified between Class II forms (increased projection of upper arch relative to the lower arch) and Class III forms (lower arch projection beyond the upper arch) in symmetrical shape variation, including anteroposterior arch discrepancies and abnormal anterior arch divergence or convergence. Staley et al, who suggested that the narrow widths of the dental arch in Class II patients appeared to be caused by palatally tipped teeth and also by narrow bony bases of the dental arch, our results showed that transverse discrepancy in Class II, division 1 patients originated from upper posterior teeth and not from the maxillary alveolar base (Staley et al., 1985; (Mehta et al., 2015; Ramadurai et al., 2019; Mathew et al., 2020).

Maxillary inter premolar, intermolar widths and all maxillary alveolar width measurements were found to be significantly narrower in the Class III group than in the normal occlusion sample. When the corresponding inter arch widths were matched correctly, the maxillary arch widths were usually narrower than the mandible arch widths. Our institution is passionate about high quality evidence-based research and has excelled in various fields. We hope this study adds to this rich legacy. Similarly, in a study they indicated that almost all the upper dental and alveolar width measurements were narrower in patients with Class III malocclusion when 
compared with the normal occlusion sample. In addition, the mandibular dental width measurements were larger in the Class III group (Uysal et al., 2005; Mehta et al., 2015; Pc et al., 2018; Ramesh et al., 2018; Ezhilarasan et al., 2019; Ramadurai et al., 2019; Sridharan et al., 2019; Vijayashree, 2019; Mathew et al., 2020). Limitations of the study was the sample included in the study. Larger sample size including a heterogenous population can be done.

\section{CONCLUSION}

Within the limitations of the study, it is concluded that U-shaped arch was most commonly seen in class 1 and class 2 division 2 malocclusion, whereas V-shaped arch is more prevalent in class 2 division 1 malocclusion and square shaped arch in class III malocclusion. Knowledge regarding arch forms and dental malocclusion would hence enhance the clinical judgement regarding the planning for orthodontic treatment.

\section{ACKNOWLEDGEMENTS}

The authors would like to thank Saveetha Dental College for providing a platform for research.

Funding: Saveetha Dental College and Hospitals, Saveetha Institute of Medical and Technical Science, Saveetha University.

\section{REFERENCES}

Drukker, W., Parsons, F. M. and Maher, J. F. (2012). Replacement of Renal Function by Dialysis: A textbook of dialysis. Springer Science \& Business Media.

Dunn, R. (1937). The Mandible and its Postnatal Development: a Study of Function and Environment as Aids in the Development of the Dental Mechanism**Read before the Section on Orthodontia at the Seventy-Eighth Annual Session of the American Dental Association, San Francisco, Calif., July 15, 1936, The Journal of the American Dental Association and The Dental Cosmos, pp. 529-542. doi: 10.14219/jada.archive.1937.0098.

Ezhilarasan, D., Apoorva, V. S. and Ashok Vardhan, N. (2019). Syzygium cumini extract induced reactive oxygen species-mediated apoptosis in human oral squamous carcinoma cells, Journal of oral pathology \& medicine: official publication of the International Association of Oral Pathologists and the American Academy of Oral Pathology, 48(2), pp. 115-121.

Gheena, S. and Ezhilarasan, D. (2019). Syringic acid triggers reactive oxygen species-mediated cytotoxicity in HepG2 cells, Human \& experimental toxicology, 38(6), pp. 694-702.

Jain, V. S. et al. (2019). Evaluation of Three-Dimensional Changes in Pharyngeal Airway Following Isolated Lefort One Osteotomy for the Correction of Vertical Maxillary Excess: A Prospective Study, Journal of maxillofacial and oral surgery, 18(1), pp. 139-146.
Jose, J., Ajitha and Subbaiyan, H. (2020). Different treatment modalities followed by dental practitioners for Ellis class 2 fracture - A questionnaire-based survey, The open dentistry journal, 14(1), pp. 59-65.

Ke, Y. et al. (2019). Photosynthesized gold nanoparticles from Catharanthus roseus induces caspase-mediated apoptosis in cervical cancer cells (HeLa), Artificial cells, nanomedicine, and biotechnology, 47(1), pp. 19381946.

Krishnaswamy, H. et al. (2020). Investigation of air conditioning temperature variation by modifying the structure of passenger car using computational fluid dynamics, Thermal science, 24(1 Part B), pp. 495-498. Leighton, B. C. (1991). Aetiology of malocclusion of the teeth, Archives of disease in childhood, 66(9), pp. 1011-1012.

Malli Sureshbabu, N. et al. (2019). Concentrated Growth Factors as an Ingenious Biomaterial in Regeneration of Bony Defects after Periapical Surgery: A Report of Two Cases, Case reports in dentistry, 2019, p. 7046203.

Mathew, M. G. et al. (2020). Evaluation of adhesion of Streptococcus mutans, plaque accumulation on zirconia and stainless steel crowns, and surrounding gingival inflammation in primary, Clinical oral investigations. Available at: https://link.springer.com/article/10.1007/ s00784-020-03204-9.

Mehta, M. et al. (2019). Oligonucleotide therapy: An emerging focus area for drug delivery in chronic inflammatory respiratory diseases, Chemico-biological interactions, 308, pp. 206-215.

Mehta, N. et al. (2015). Evaluation of arch width among Class I normal occlusion, Class II Division 1, Class II Division 2, and Class III malocclusion in Indian population, Contemporary Clinical Dentistry, p. 202. doi: 10.4103/0976-237x.166842.

Muthukrishnan, S. et al. (2020). Support vector machine for modelling and simulation of heat exchangers, Thermal science, 24(1 Part B), pp. 499-503.

Onyeaso, C. O. and Sanu, O. O.(2005). Perception of personal dental appearance in Nigerian adolescents, American Journal of Orthodontics and Dentofacial Orthopedics, pp. 700-706. doi: 10.1016/j.ajodo.2003.12.028.

Pc, J., Marimuthu, T. and Devadoss, P. (2018). Prevalence and measurement of anterior loop of the mandibular canal using CBCT: A cross sectional study, Clinical implant dentistry and related research. Available at: https:// europepmc.org/article/med/29624863.

Proffit, W. R. (1986). On the Aetiology of Malocclusion, British Journal of Orthodontics, pp. 1-11. doi: 10.1179/ bjo.13.1.1.

Ramadurai, N. et al. (2019). Effectiveness of $2 \%$ Articaine as an anesthetic agent in children: randomized controlled trial, Clinical oral investigations, 23(9), pp. 3543-3550. 
Ramesh, A. et al. (2018). Comparative estimation of sulfiredoxin levels between chronic periodontitis and healthy patients - A case-control study, Journal of periodontology, 89(10), pp. 1241-1248.

Samuel, M. S. et al. (2019). Efficient removal of Chromium(VI) from aqueous solution using chitosan grafted graphene oxide (CS-GO) nanocomposite, International journal of biological macromolecules, 121, pp. 285-292.

Samuel, S. R., Acharya, S. and Rao, J. C. (2020). School Interventions-based Prevention of Early-Childhood Caries among 3-5-year-old children from very low socioeconomic status: Two-year randomized trial, Journal of public health dentistry, 80(1), pp. 51-60.

Sathish, T. and Karthick, S. (2020). Wear behaviour analysis on aluminium alloy 7050 with reinforced SiC through taguchi approach, Journal of Japan Research Institute for Advanced Copper-Base Materials and Technologies, 9(3), pp. 3481-3487.

Sharma, P. et al. (2019). Emerging trends in the novel drug delivery approaches for the treatment of lung cancer, Chemico-biological interactions, 309, p. 108720.

Sridharan, G. et al. (2019). Evaluation of salivary metabolomics in oral leukoplakia and oral squamous cell carcinoma, Journal of oral pathology \& medicine: official publication of the International Association of Oral Pathologists and the American Academy of Oral Pathology, 48(4), pp. 299-306.

Staley, R. N., Stuntz, W. R. and Peterson, L. C. (1985). A comparison of arch widths in adults with normal occlusion and adults with Class II, Division 1 malocclusion, American Journal of Orthodontics, pp. 163-169. doi: 10.1016/0002-9416(85)90241-6.

Strang, R. H. W. (1946). Factors of influence in producing a stable result in the treatment of malocclusion, American Journal of Orthodontics and Oral Surgery, pp. 313-332. doi: 10.1016/0096-6347(46)90123-8.

Uysal, T. et al. (2005). Dental and alveolar arch widths in normal occlusion and Class III malocclusion, The Angle orthodontist, 75(5), pp. 809-813.

Varghese, S. S., Ramesh, A. and Veeraiyan, D. N. (2019). Blended Module-Based Teaching in Biostatistics and Research Methodology: A Retrospective Study with Postgraduate Dental Students, Journal of dental education, 83(4), pp. 445-450.

Varma, R. B. et al. (2005). Oral health status of 5 years and 12 years school going children in Chennai city An epidemiological study, Journal of Indian Society of Pedodontics and Preventive Dentistry, p. 17. doi: 10.4103/0970-4388.16021.

Venu, H., Raju, V. D. and Subramani, L. (2019). Combined effect of influence of nano additives, combustion chamber geometry and injection timing in a DI diesel engine fuelled with ternary (diesel-biodiesel-ethanol) blends, Energy, 174, pp. 386-406.

Venu, H., Subramani, L. and Raju, V. D. (2019). Emission reduction in a DI diesel engine using exhaust gas recirculation (EGR) of palm biodiesel blended with $\mathrm{TiO} 2$ nano additives, Renewable Energy, 140, pp. 245-263.

Vignesh, R. et al. (2019). Management of Complicated Crown-Root Fracture by Extra-Oral Fragment Reattachment and Intentional Reimplantation with 2 Years Review, Contemporary clinical dentistry, 10(2), pp. 397-401.

Vijayashree P. J. (2019). In silico validation of the non-antibiotic drugs acetaminophen and ibuprofen as antibacterial agents against red complex pathogens, Journal of periodontology, 90(12), pp. 1441-1448.

Walther, D. P. and Houston, W. J. B. (1983) Walther's Orthodontic Notes. Butterworth-Heinemann.

Weinstein, G. M. and Zientz, M. T. (2016). The Dental Reference Manual: A Daily Guide for Students and Practitioners. Springer. 